\title{
Comparison of Adhesion and Retention Forces for Two Candidate Docking Seal Elastomers
}

Brad D. Hartzler

The University of Akron, Akron, Ohio

Marta B. Panickar

The University of Mississippi, University, Mississippi

Janice L. Wasowski and Christopher C. Daniels

The University of Akron, Akron, Ohio 


\section{NASA STI Program . . . in Profile}

Since its founding, NASA has been dedicated to the advancement of aeronautics and space science. The NASA Scientific and Technical Information (STI) program plays a key part in helping NASA maintain this important role.

The NASA STI Program operates under the auspices of the Agency Chief Information Officer. It collects, organizes, provides for archiving, and disseminates NASA's STI. The NASA STI program provides access to the NASA Aeronautics and Space Database and its public interface, the NASA Technical Reports Server, thus providing one of the largest collections of aeronautical and space science STI in the world. Results are published in both non-NASA channels and by NASA in the NASA STI Report Series, which includes the following report types:

- TECHNICAL PUBLICATION. Reports of completed research or a major significant phase of research that present the results of NASA programs and include extensive data or theoretical analysis. Includes compilations of significant scientific and technical data and information deemed to be of continuing reference value. NASA counterpart of peer-reviewed formal professional papers but has less stringent limitations on manuscript length and extent of graphic presentations.

- TECHNICAL MEMORANDUM. Scientific and technical findings that are preliminary or of specialized interest, e.g., quick release reports, working papers, and bibliographies that contain minimal annotation. Does not contain extensive analysis.

- CONTRACTOR REPORT. Scientific and technical findings by NASA-sponsored contractors and grantees.
- CONFERENCE PUBLICATION. Collected papers from scientific and technical conferences, symposia, seminars, or other meetings sponsored or cosponsored by NASA.

- SPECIAL PUBLICATION. Scientific, technical, or historical information from NASA programs, projects, and missions, often concerned with subjects having substantial public interest.

- TECHNICAL TRANSLATION. Englishlanguage translations of foreign scientific and technical material pertinent to NASA's mission.

Specialized services also include creating custom thesauri, building customized databases, organizing and publishing research results.

For more information about the NASA STI program, see the following:

- Access the NASA STI program home page at http://www.sti.nasa.gov

- E-mail your question via the Internet to help@ sti.nasa.gov

- Fax your question to the NASA STI Help Desk at $443-757-5803$

- Telephone the NASA STI Help Desk at 443-757-5802

- Write to: NASA Center for AeroSpace Information (CASI) 7115 Standard Drive Hanover, MD 21076-1320 


\section{Comparison of Adhesion and Retention Forces for Two Candidate Docking Seal Elastomers}

\section{Brad D. Hartzler}

The University of Akron, Akron, Ohio

Marta B. Panickar

The University of Mississippi, University, Mississippi

Janice L. Wasowski and Christopher C. Daniels

The University of Akron, Akron, Ohio

Prepared for the

52nd Structures, Structural Dynamics, and Materials Conference

cosponsored by AIAA, ASME, ASCHE, AHS, and ASC

Denver, Colorado, April 4-7, 2011

Prepared under Contract NNC08CA35C

National Aeronautics and

Space Administration

Glenn Research Center

Cleveland, Ohio 44135 


\section{Acknowledgments}

The authors wish to thank Esterline Technologies and Custom Rubber Corp for providing the test samples used during the course of this investigation and NASA Glenn Research Center for access to their test facilities. The authors greatly appreciate the technical support provided by Richard Tashjian and William Anderer, without which, this work would not have been completed. This work was supported by the National Aeronautics and Space Administration under contract NNC08CA35C.

Trade names and trademarks are used in this report for identification only. Their usage does not constitute an official endorsement, either expressed or implied, by the National Aeronautics and Space Administration.

Level of Review: This material has been technically reviewed by NASA technical management.

Available from

NASA Center for Aerospace Information 7115 Standard Drive

Hanover, MD 21076-1320
National Technical Information Service 5301 Shawnee Road Alexandria, VA 22312

Available electronically at http://www.sti.nasa.gov 


\title{
Comparison of Adhesion and Retention Forces for Two Candidate Docking Seal Elastomers
}

\author{
Brad D. Hartzler \\ The University of Akron \\ Akron, Ohio 44325 \\ Marta B. Panickar \\ The University of Mississippi \\ University, Mississippi 38677 \\ Janice L. Wasowski and Christopher C. Daniels \\ The University of Akron \\ Akron, Ohio 44325
}

\begin{abstract}
To successfully mate two pressurized vehicles or structures in space, advanced seals are required at the interface to prevent the loss of breathable air to the vacuum of space. A critical part of the development testing of candidate seal designs was a verification of the integrity of the retaining mechanism that holds the silicone seal component to the structure. Failure to retain the elastomer seal during flight could liberate seal material in the event of high adhesive loads during undocking. This work presents an investigation of the force required to separate the elastomer from its metal counter-face surface during simulated undocking as well as a comparison to that force which was necessary to destructively remove the elastomer from its retaining device. Two silicone elastomers, Wacker 00749524 and Esterline ELA-SA-401, were evaluated. During the course of the investigation, modifications were made to the retaining devices to determine if the modifications improved the force needed to destructively remove the seal. The tests were completed at the expected operating temperatures of $-50,+23$, and $+75^{\circ} \mathrm{C}$. Under the conditions investigated, the comparison indicated that the adhesion between the elastomer and the metal counter-face was significantly less than the force needed to forcibly remove the elastomer seal from its retainer, and no failure would be expected.
\end{abstract}

\section{Introduction}

Seals are used to maintain gases at desired pressures within a spacecraft. For docking systems, seals between adjoining vehicles are typically a face seal configuration. A face seal configuration allows for easy assembly onorbit with minimal mechanical mechanisms while reducing the possibility of damage due to scrubbing that may occur with other seal configurations. However, face seal configurations place the seal and its retention mechanism into tension during undocking, risking seal damage and removal.

Elastomer compounds have been found to develop considerable adhesion when compressed against metallic surfaces with various coatings. Quantifying the amount of separation force required to undock the seal from its mating counter-face is a part of ongoing research (Refs. 1 to 6). Elastomer surface treatments have been shown to dramatically reduce, but not completely eliminate, adhesion between elastomer seals and their counter-faces (Refs. 2 and 6). This introduces the possibility that the elastomer seal-to-mating counter-face adhesion may exceed the forces retaining the seal to its host vehicle (Ref. 6). It is critical that the seal not be dislodged or damaged during operation, as this could liberate orbital debris, potentially impairing sealing ability and redundancy. Additionally, damage to a space seal can be a costly disruption to normal operations.

The undocking of a seal from its mating counter-face surface may occur at any temperature within the operational envelope. For docking systems, this temperature may range from as low as $-50^{\circ} \mathrm{C}$ to as high as $+75^{\circ} \mathrm{C}$ (Ref. 7). Over this temperature range, the tensile strength of the elastomer may vary substantially thereby affecting the structural strength of the elastomer part. 
During the course of this work, a candidate seal design was evaluated to determine the adhesion that may occur between the seal and its mating counter-face surface. The candidate seal was a two-part design, including both an elastomer and a metal retainer. The silicone elastomer was manufactured separate from the metal retainer, which was designed to mechanically retain the elastomer to the host space vehicle. This design was investigated utilizing two different silicone elastomer compounds. Additionally, the work presented herein quantified the strength of the retaining features of two silicone elastomer candidate seal materials by determining the amount of force required to extract silicone elastomer seals from their retainers. The presented data was acquired from tests on individual subscale seal assemblies at $-50,+23$, and $+75^{\circ} \mathrm{C}$.

\section{Experimental Setup}

\section{A. Test Specimens}

The test specimen seal design consisted of two separate components, a two-bulb elastomer seal and a metal retainer. Two silicone elastomer compounds were considered: Esterline Corporation ELA-SA-401 silicone elastomer manufactured by Kirkhill-TA and Wacker 007-49524 silicone elastomer manufactured by Custom Rubber Corp. Select mechanical properties of ELA-SA-401 and 007-49524 were shown in Table 1. Both elastomers were vacuum molded into a shape consisting of two seal bulbs connected by a retaining web feature, see Figure 1 . The two bulb design of a primary (inner) seal and redundant (outer) seal provides single fault tolerance to leak rate failure. The outside diameter of the elastomer was approximately $30 \mathrm{~cm}$ for all test specimens used.

The elastomer part was tested without any surface pretreatment that may be used to reduce the elastomer's natural adhesive tendencies (Refs. 6 and 9). All test specimens were cleaned of any surface dirt and debris by gently rubbing the surface with a lint-free cloth soaked with isopropyl alcohol. The test specimen was allowed to dry prior to testing.

The metal retainer of the two-part test specimens was manufactured from aluminum 7075-T651. The surface roughness of the aluminum retainer was $0.41 \mu \mathrm{m}$ or better prior to the application of an anodized surface finish. The metal retainer was designed to fit between the two elastomer seal bulbs when the elastomer and metal components were assembled onto the test fixture, see Figure 2.

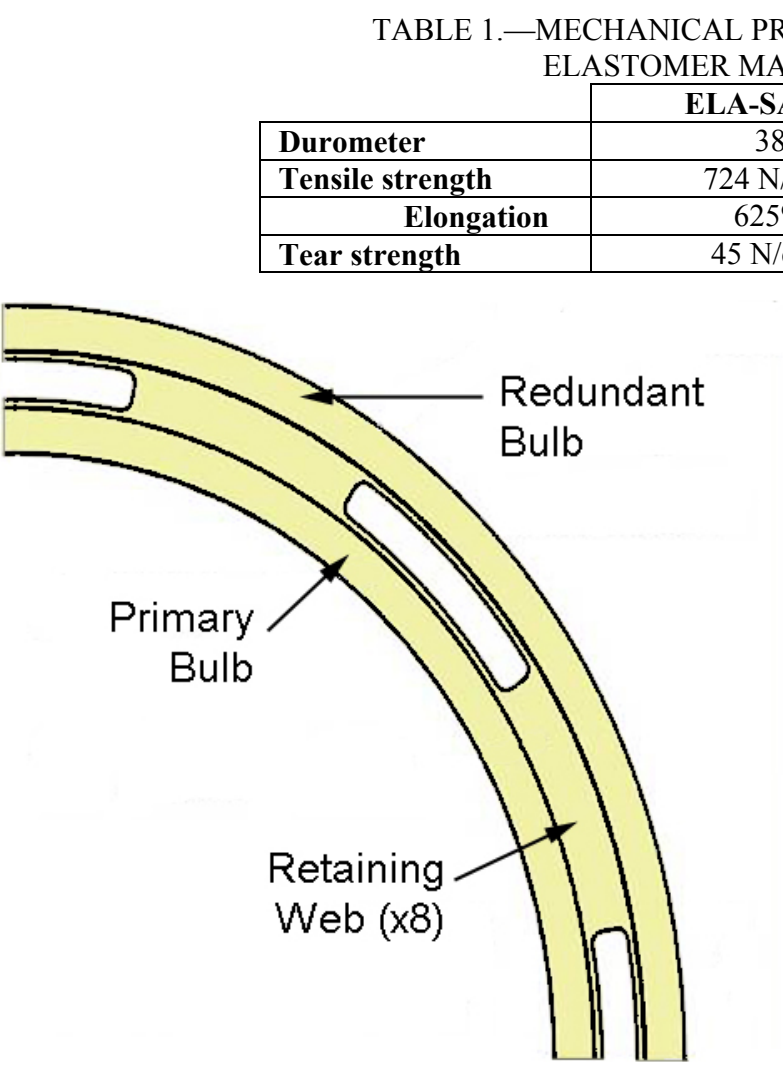

Figure 1.--lllustration of the top view of the elastomer seal of the two-part test specimen.

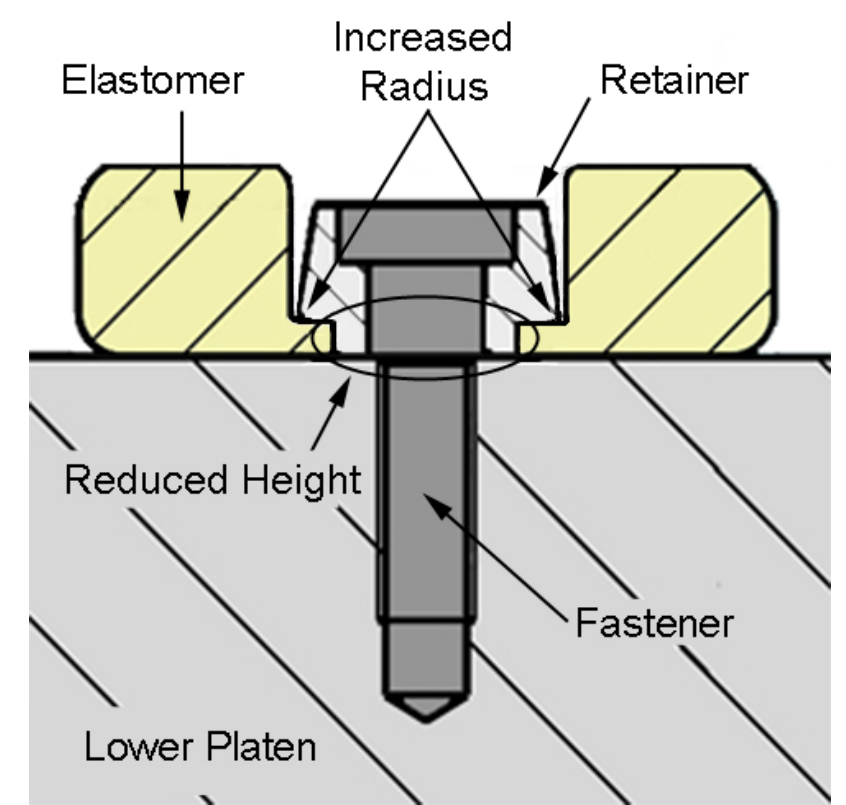

Figure 2.-Illustration of the cross-section of the two-part seal assembly. 
Select destructive removal tests were conducted using metal retainers that were modified. These modifications included increasing the radii of the retainers' edges that contact the elastomer and decreasing the height of the retainers' pads, as highlighted in Figure 2.

\section{B. Test Fixture Assembly}

\section{Retention Failure Tests}

The test fixture consisted of one aluminum platen (lower) and one carbon steel platen (upper), in between which the seal assembly was positioned and held, see Figure 3. The elastomer part of the test specimen was attached to the lower platen using the metal retainer and \#8-32 size fasteners. As the upper surface of the seal assembly was intended to be the reusable interface, adhesive was utilized to simulate an intentionally excessive level of adhesion to the opposing mating counter-face (the upper platen).

Dow Corning 3145 RTV MIL-A-46146 was used to bond the complete circumference of a single elastomer bulb to the upper platen, utilizing GE Silicone SS4004P primer prior to seal attachment. The test specimen and fixture assembly was cured at $74 \pm 3^{\circ} \mathrm{C}$ for 24 to 48 hours to ensure that the RTV was fully cured.

To quantify the amount of force necessary to extract the elastomer seal from its metal retainer, the test fixture was coaxially aligned and fastened to the actuator rods of an actuation system, as discussed in further detail in Section C.

\section{Adhesion Test}

The test fixture used to determine the adhesion force between the elastomer component of the seal assembly and its metal counter-face was similar to that which was described in the previous section. The differences were that both the lower and upper platens were made of aluminum, 6061-T651, with a $0.41 \mu \mathrm{m}$ surface roughness or better prior to surface treatment. A 0.008 to $0.013 \mathrm{~mm}$ thick coating of electroless nickel was applied to both platens. No adhesive was applied to the surface of either the elastomer or its counter-face, allowing the natural adhesive tendency to be quantified.

\section{Actuation and Temperature Control Systems}

The actuation system consisted of an Instron 5584 electromechanical load frame with a temperature control system incorporated, see Figure 4. For each trial, the upper platen was fastened into the load frame using a 5/8"- 18 threaded connection. The lower platen was attached to an aluminum platen using four $3 / 8$ "-16 screws. The aluminum platen was fastened to the load frame using a single $5 / 8$ "- 18 threaded connection.

The temperature of elevated $\left(+75^{\circ} \mathrm{C}\right)$ and chilled $\left(-50^{\circ} \mathrm{C}\right)$ temperature tests was controlled using an Instron 3119-407 environmental control system. The system surrounded the test specimen assembly and its attachments to the load frame. For elevated and chilled temperature tests, the fixture was brought to a steady state temperature within $\pm 5^{\circ} \mathrm{C}$ of the desired set point prior to testing; cooling of the fixture was carried out with the use of liquid nitrogen. The temperature of the room temperature tests $\left(+23^{\circ} \mathrm{C}\right)$ was uncontrolled.

The rate of separation was not uniform, but followed the curve shown in Figure 5.

\section{Instrumentation}

The force required by the actuation system to remove the elastomer from its retaining feature or to separate the elastomer from its counter-face was measured by an Interface 1020ACK-12-5K-B load cell. As the load cell was mounted external to the temperature control system, the error of the load cell due to test temperature was negligible. The load cell and its reported measurements had an accuracy of $\pm 0.24 \%$ of the reading for both the destructive removal and adhesion tests.

Data was collected at a sampling rate of $40 \mathrm{~Hz}$ and written to a PC-based recording device.

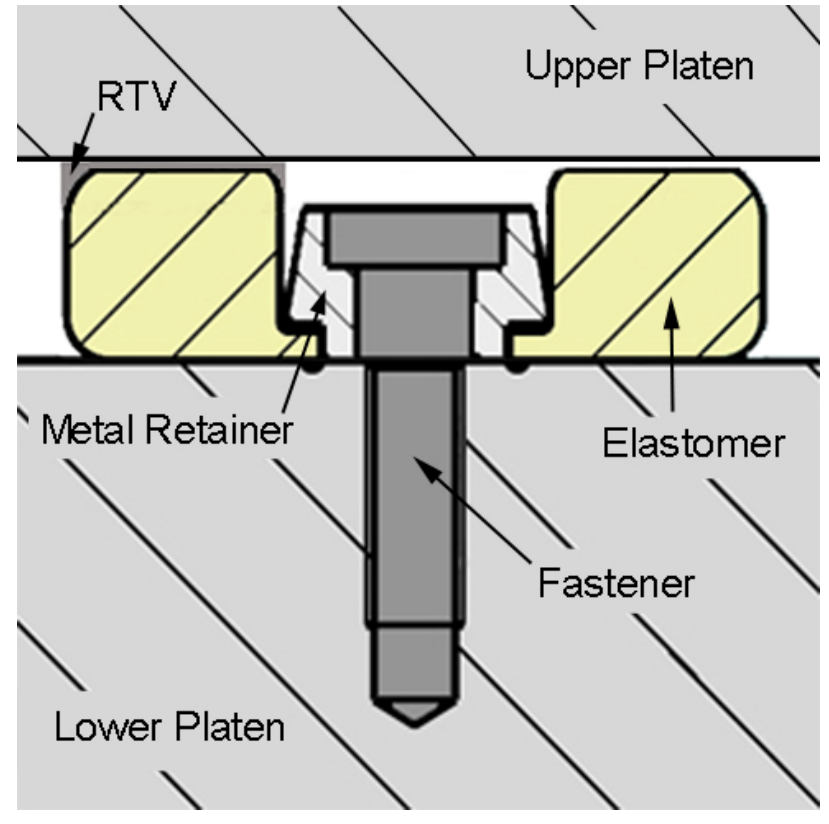

Figure 3.-Illustration of the cross-section of the seal assembly and the location of the adhesive. 


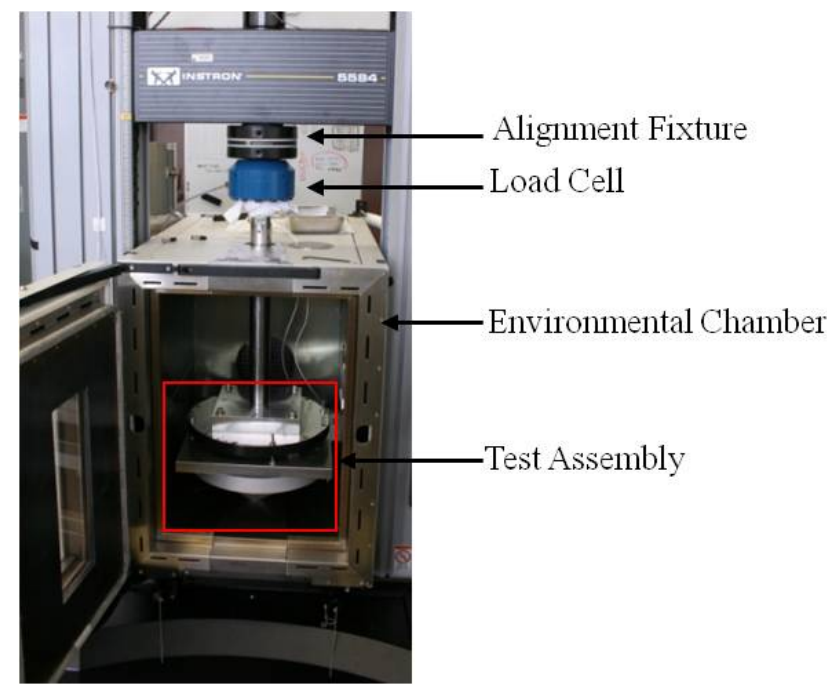

Figure 4.-Photograph of the actuation and temperature control system.

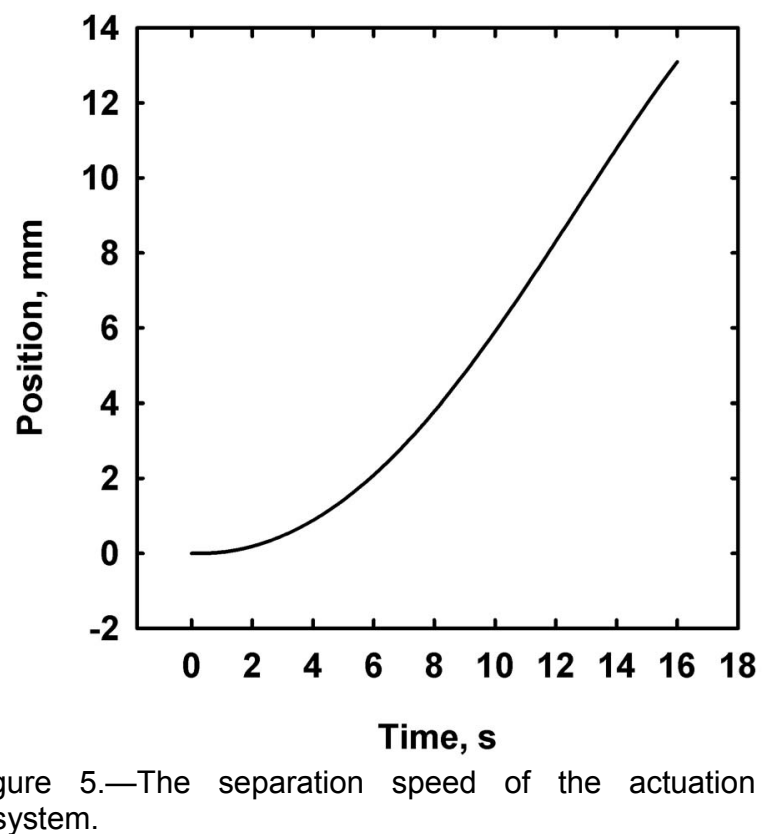

\section{Results and Discussion}

The force required to fail the retention mechanism holding the elastomer in its retainer (referred to as "removal force" or "retention force") was quantified at test temperatures of $-50,+23$, and $+75^{\circ} \mathrm{C}$. The obtained retention failure forces were compared to adhesion force values observed in simulated undocking cycles of the same seal design against an electroless nickel plated aluminum platen at the three test temperatures. To facilitate comparisons between tests and designs, the forces were divided by the circumferential length of elastomer seal tested to obtain a normalized force per unit length.

\section{A. Retention Failure Force}

A total of two, five test series, were conducted on the two-part seal test specimens. In the first series, the tests were conducted at each of the three test temperatures, $-50,+23$ and $+75^{\circ} \mathrm{C}$, for both elastomer compounds. During these tests, it was observed that the retention failure occurred at the contact point between the elastomer and the mechanical metal retainer. In the second series of tests, the retainer was modified as highlighted in Figure 2. In the first modification, the retainer was machined to provide a larger radius at the location where the elastomer and retainer were in contact during extraction. A single test was completed for each material at room temperature. A further modification was investigated; the second modification included the first modification along with a reduction in height of the metal retainer such that the elastomer web was placed in compression upon installation.

In general, the two elastomer compounds behaved in a similar fashion. Upon separation of the upper and lower platens, the elastomer part that was adhered to the upper platen with RTV remained in contact with the upper platen. The metal retainer attached to the lower platen remained fastened to the lower platen. The retaining web, see Figure 1, exhibited extraordinary deformation as shown in the photograph in Figure 6. During this interval, the specimen resisted the maximum amount of force, see Figure 7, as the elastomer reoriented itself under the metal retainer (between 0.0 and $2.0 \mathrm{~cm}$ displacement). The elastomer continued to deform until the first of the eight retaining webs failed (approximately $4.0 \mathrm{~cm}$ for the $-50^{\circ} \mathrm{C}$ case). The upper and lower platens continued to separate until all eight retaining webs failed, with the force decreasing with each web failure.

The elastomer exhibited the lowest amount of elongation prior to complete failure at $+75^{\circ} \mathrm{C}$. This was presumed to be caused by a decrease in the strength of the elastomer at elevated temperatures, which caused the retaining web feature to fail at lower levels of displacement. Decreased strength at elevated temperatures also allowed the elastomer to reorient itself under the metal retainer with lower levels of applied force. 


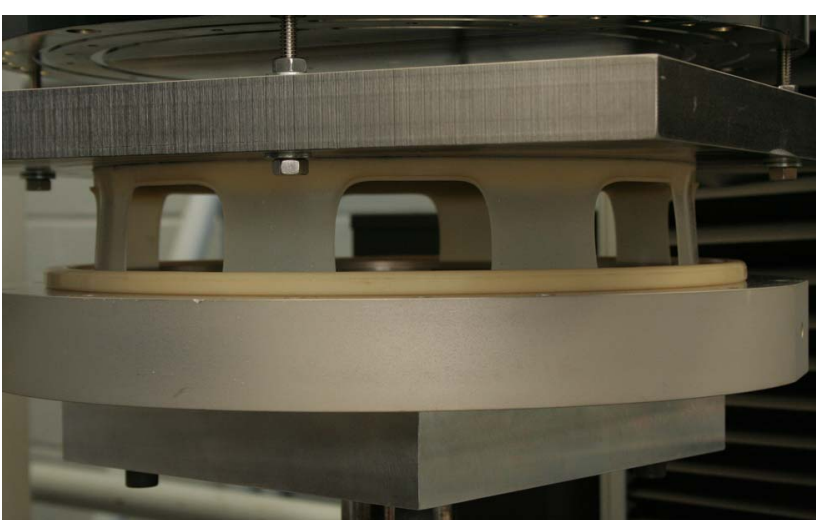

Figure 6.-Photograph of an ELA-SA-401 specimen during a test at $+23^{\circ} \mathrm{C}$ prior to failure.

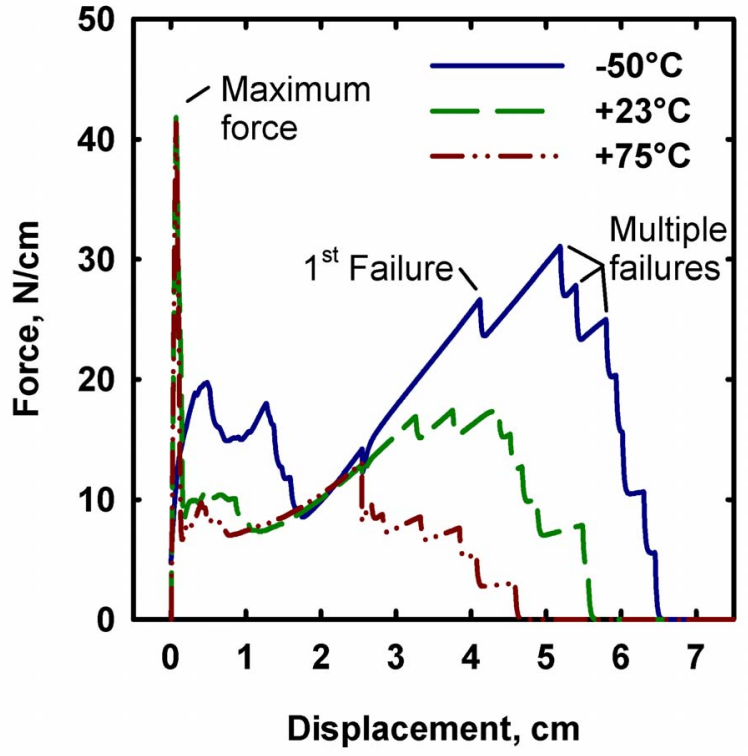

Figure 7.-Force-displacement response of the 00749524 specimen without retainer modification at -50 , +23 , and $+75^{\circ} \mathrm{C}$.
The results of the first series of tests performed to determine the effect of test temperature on the maximum force resisted by the seal assemblies before retention failure are shown in Figure 8 . The force resisted by the 007-49524 compound remained relatively stable across the temperatures of interest. The ELA-SA-401 compound showed a marked decrease in the force resisted prior to failure with increasing test temperature.

As the seal was intended to operate across the range of temperatures examined, only the lowest observed force to cause retention failure was of interest for a given compound. For the 007-49524 compound, that value was $31.1 \mathrm{~N} / \mathrm{cm}\left(\right.$ at $-50^{\circ} \mathrm{C}$ ); for the ELA-SA-401 compound, $38.9 \mathrm{~N} / \mathrm{cm}\left(\right.$ at $\left.+75^{\circ} \mathrm{C}\right)$.

In general, the force required to remove the ELA-SA-401 exceeded that which was needed to remove the 007-49524. For the one experiment conducted on each elastomer at room temperature, the difference was $21 \%$. This was greater than the $10 \%$ greater tensile strength, as shown in Table 1.

To determine if minor changes to the retainer design would significantly increase the force necessary to remove the elastomer component from its retainer, two subsequent tests were conducted after retainer modification, as highlighted in Figure 2. As shown in Figure 9, neither increasing the radius of the retainer nor reducing the height of the elastomer improved the retaining performance for the 007-49524 elastomer compound. The removal force was reduced by 24 and $36 \%$ with those individual modifications, respectively. The individual modifications produced modest improvements in removal force, 6 and $18 \%$ respectively, with the ELA-SA-401 compound, as shown in Figure 10.

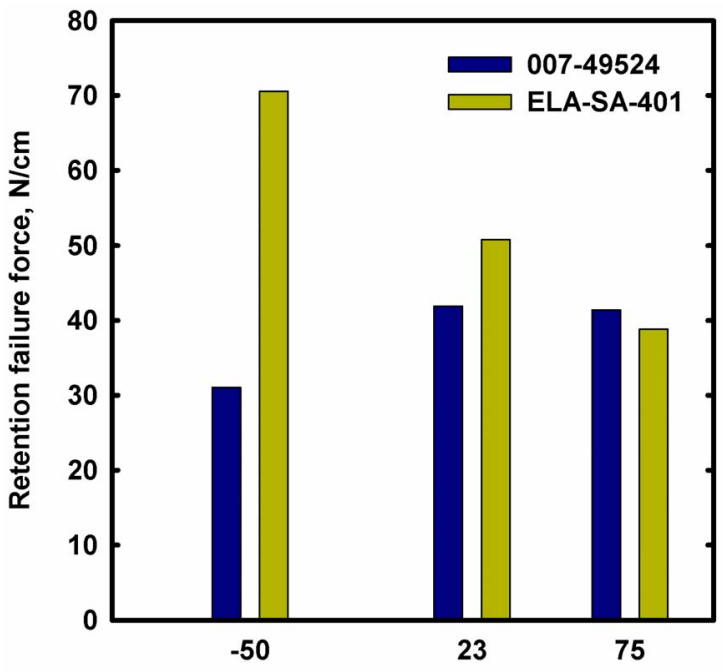

Figure 8.-Maximum force resisted by the seal assemblies of the two materials in the first series of tests at $-50,+23$, and $+75^{\circ} \mathrm{C}$. 


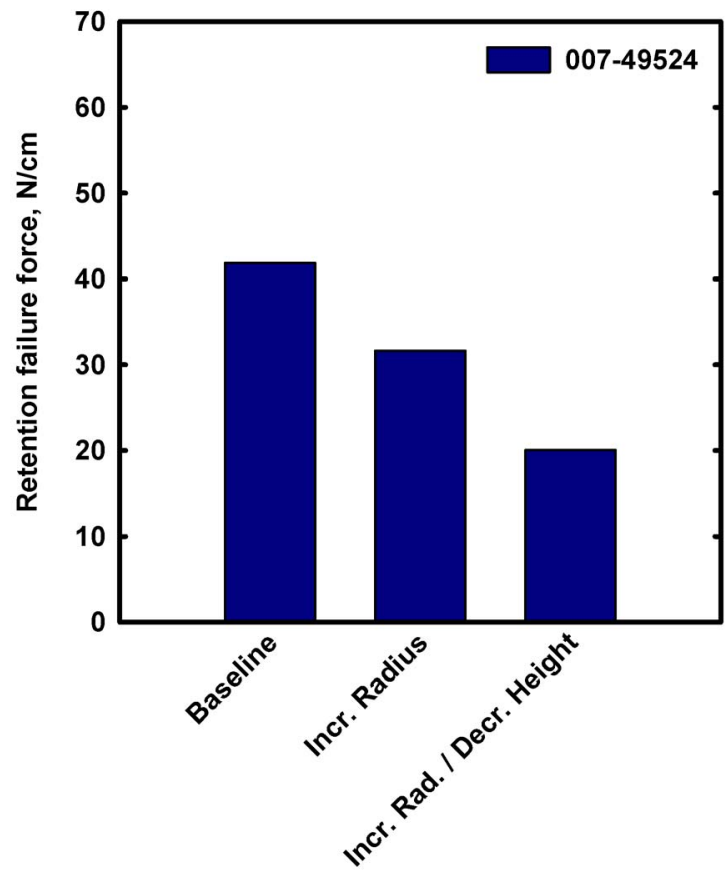

Retainer design

Figure 9.--Retention failure forces of Wacker 007-49524 for three retainer designs tested at $+23^{\circ} \mathrm{C}$.

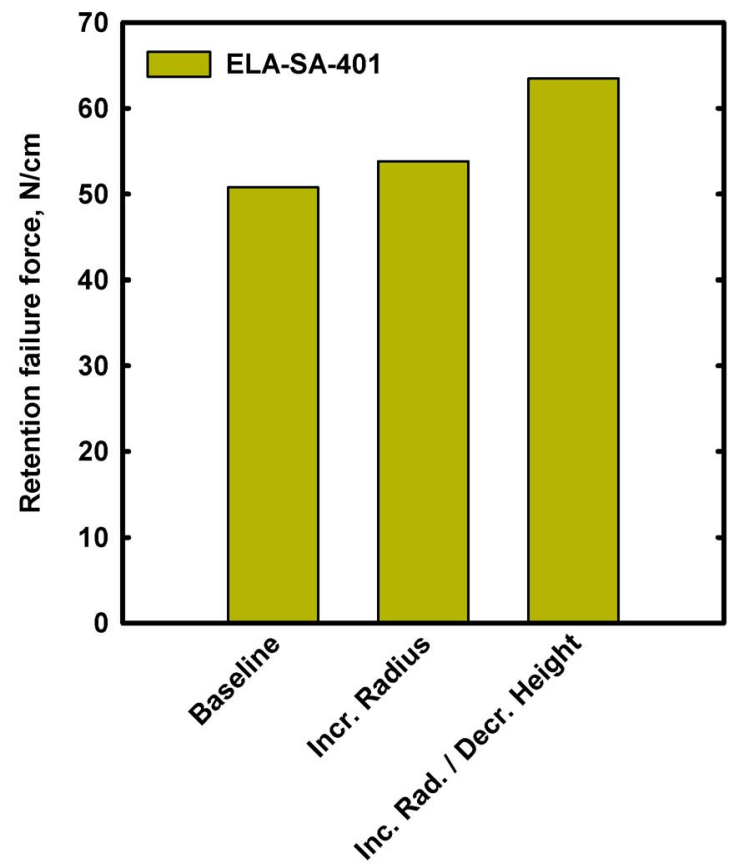

Retainer design

Figure 10.--Retention failure forces of Esterline ELA-SA401 for three retainer designs tested at $+23^{\circ} \mathrm{C}$.

\section{B. Adhesion Force}

The amount of adhesion between the elastomer seal and its mating counter-face (without adhesive) was measured for each of the two elastomer compounds. Measurements were recorded at each of three temperatures: $-50,+23$, and $+75^{\circ} \mathrm{C}$. At room temperature, the specimens were held together for extended periods of dwell time to determine the effect of time.

For both of the elastomer compounds investigated, the highest value of adhesion was recorded when the compression, dwell, and separation occurred at $-50^{\circ} \mathrm{C}$, see Figures 11 and 12 . The highest value of adhesion was 3.5 and $8.0 \mathrm{~N} / \mathrm{cm}$ for the 007-49524 and ELA-SA-401 compounds, respectively. This observation was in agreement with those of other studies (Refs. 2 and 6) and was attributed to an increase in surface energy at cold temperatures. Conversely, the tests conducted at the highest temperature, $+75^{\circ} \mathrm{C}$, exhibited the least adhesion.

At room temperature, $+23^{\circ} \mathrm{C}$, the test specimens were held in compression for up to 72 hours. Intuitively, the level of adhesion was expected to rise with increased dwell times. For the 007-49524 compound, this was the trend observed; however the increase was modest, from 0.59 to $1.4 \mathrm{~N} / \mathrm{cm}$, when the dwell time was increased from 2 to 72 hours, see Figure 11.

No significant increase in adhesion level was observed with the dwell times investigated in this study for the ELA-SA-401 compound at $+23^{\circ} \mathrm{C}$, see Figure 12. The highest level recorded for this dwell time was $3.4 \mathrm{~N} / \mathrm{cm}$ after 24 hours of compression. The range of adhesion was 0.36 to $8.0 \mathrm{~N} / \mathrm{cm}$ with the largest value recorded after 2 hours at $-50^{\circ} \mathrm{C}$.

\section{Effect of Separation Speed}

As discussed above, the adhesion force showed a strong dependence on temperature and no more than modest dependence on dwell time. In addition to these factors, the displacement of the elastomer seal at the moment of separation was dependent on the amount of adhesion. Since the unloading rate was not uniform, as illustrated in Figure 5, the speed at which the separation occurred was variable over the experimental test conditions. Therefore, an understanding of the effect of separation speed on the adhesion force was a required element of the investigation. 


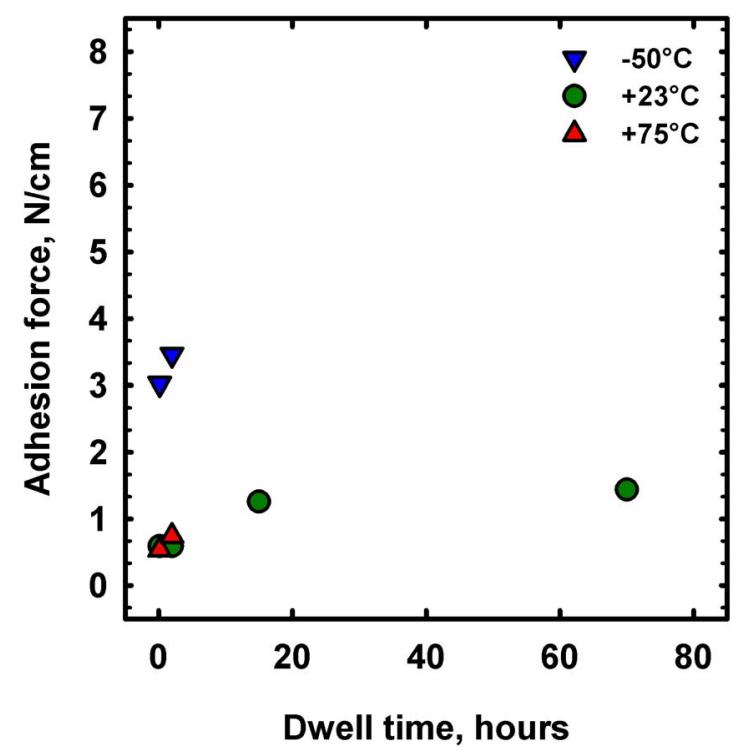

Figure 11.-Maximum adhesion force of 007-49524 observed after various compression dwell periods at $-50,+23$, and $+75^{\circ} \mathrm{C}$.

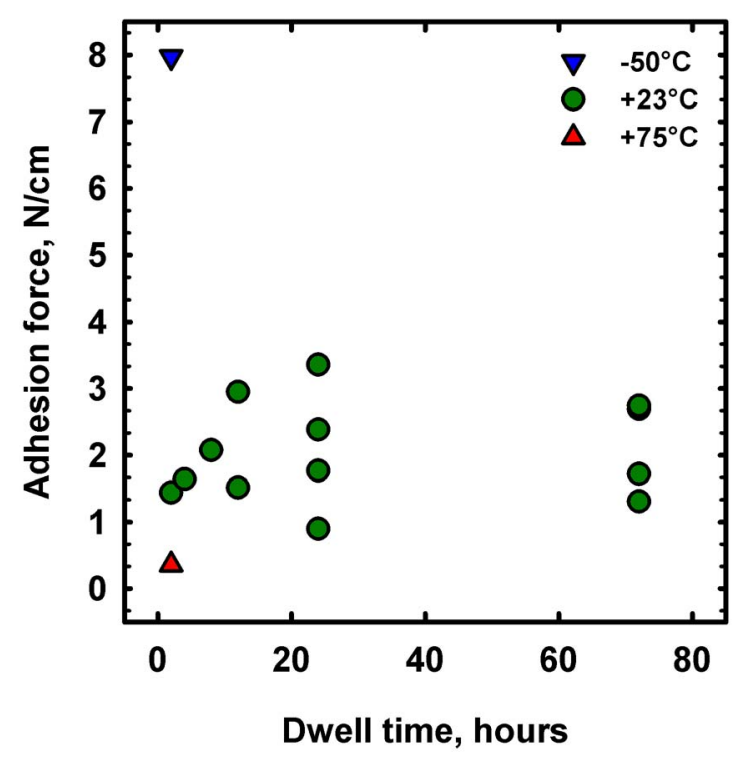

Figure 12.-Maximum adhesion force of ELA-SA401 observed after various compression dwell periods at $-50,+23$, and $+75^{\circ} \mathrm{C}$.

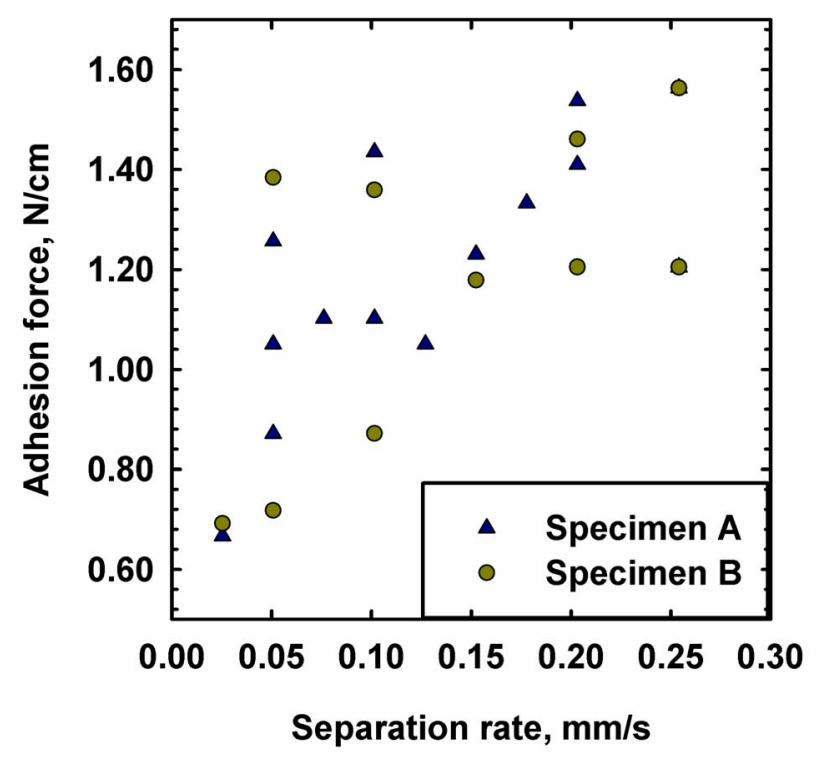

Figure 13.-Adhesion force of ELA-SA-401 at $+23^{\circ} \mathrm{C}$ after 2 hour compression.

A series of experiments was conducted on the ELA-SA-401 elastomer compound at room temperature, $+23^{\circ} \mathrm{C}$, after being held together for two hours. It was assumed that the separation between the elastomer and counter-face occurred between 0.00 and $0.26 \mathrm{~mm}$ of displacement. From Figure 5, the speed over that displacement interval was 0.00 to $0.25 \mathrm{~mm} / \mathrm{s}$.

The experiments were conducted on two identical specimens in a random order to minimize any trends that may have occurred with compression/separation cycle count. As shown in Figure 13, the adhesion force tended to increase with the rate of separation. The maximum adhesion was observed at the maximum separation rate tested, $0.25 \mathrm{~mm} / \mathrm{s}$. Conversely, the minimum adhesion occurred at the slowest speed. 


\section{Comparison Between the Retention and Adhesion Forces}

A summary table of the retention and adhesion forces described in the previous sections was presented in Table 2. As the adhesion force testing was conducted using the baseline retainer design, only the results from the baseline case were considered in the comparison.

As shown in the table, the retention force exceeded the adhesion force for both elastomers tested at all temperatures by at least a factor of 8.9 and 8.8 for the 007-49524 and ELA-SA-401 compounds, respectively. Therefore, the natural adhesion between the elastomer and its mating counter-face would not be sufficient to cause the undesired removal of the elastomer during separation.

TABLE 2.-SUMMARY OF MINIMUM RETENTION AND MAXIMUM ADHESION FORCES OF BASELINE RETAINER TESTS

\begin{tabular}{|l|c|c|c|c|c|c|}
\cline { 2 - 7 } \multicolumn{1}{c|}{} & \multicolumn{3}{c|}{ Retention force, $\mathbf{N} / \mathbf{c m}$} & \multicolumn{3}{c|}{ Maximum adhesion force, $\mathbf{N} / \mathbf{c m}$} \\
\cline { 2 - 7 } \multicolumn{1}{c|}{} & $\mathbf{- 5 0 ^ { \circ }} \mathbf{C}$ & $\mathbf{+ 2 3}{ }^{\circ} \mathbf{C}$ & $+\mathbf{7 5}^{\circ} \mathbf{C}$ & $\mathbf{- 5 0}^{\circ} \mathbf{C}$ & $+\mathbf{2 3}^{\circ} \mathbf{C}$ & $+75^{\circ} \mathbf{C}$ \\
\hline Wacker 007-49524 & 31.1 & 41.4 & 41.9 & 3.5 & 0.59 & 0.74 \\
\hline Esterline ELA-SA-401 & 70.5 & 50.9 & 38.9 & 8.0 & 3.4 & 0.36 \\
\hline
\end{tabular}

\section{Summary}

During the retention failure tests of both elastomer compounds, the elastomer component of the seal assembly failed at the web between the two seal bulbs due to excessive stretching across the metal retainer. Increasing the temperature of the test specimens decreased the force required to fail a design, due to the decreased strength of the elastomer. The amount of force resisted by the seal assemblies prior to destructive removal was 31 to $42 \mathrm{~N} / \mathrm{cm}$ for the Wacker 007-49524 compound and 39 to $71 \mathrm{~N} / \mathrm{cm}$ for the Esterline ELA-SA-401 compound.

The natural adhesion between the elastomer component of the seal assembly and its metal mating counter-face was shown to be less than $8 \mathrm{~N} / \mathrm{cm}$ for both elastomer compounds. The level of adhesion was highest at the coldest temperature tested, $-50^{\circ} \mathrm{C}$. Increasing the length of time the test specimens were held compressed did not significantly affect the adhesion level observed.

The results of the destructive retention and adhesion tests conducted during the course of this investigation showed that the candidate docking seal designs were resistant to failure due to adhesive loads that may be encountered during operation.

\section{References}

1. Bastrzyk, M.B., Garafolo, N.G., and Daniels, C.C., "The Mechanical Performance of Subscale Candidate Elastomer Docking Seal," 51st AIAA/ASME/ASCE/AHS/ASC Structures, Structural Dynamics, and Materials Conference, Orlando, Florida, AIAA-2010-3129, 2010.

2. Garafolo, N.G., Bastrzyk, M.B., and Daniels, C.C., "The Effects of Atomic Oxygen on the Sealing and Mechanical Performance of an Elastomer Seal," 48th AIAA Aerospace Sciences Meeting, Orlando, Florida, AIAA-2010-1440.

3. Daniels, C.C., de Groh III, H.C., Dunlap, Jr., P.H., Finkbeiner, J.R., Steinetz, B.M., Bastrzyk, M.B., Oswald, J.J., Banks, B.A., Dever, J.A., Miller, S.K., and Waters, D.L., "Characteristics of Elastomer Seals Exposed to Space Environments," 43rd AIAA/ASME/SAE/ASEE Joint Propulsion Conference \& Exhibit, Cincinnati, Ohio, AIAA2007-5741, 2007.

4. Daniels, C.C., Oswald, J.J., Bastrzyk, M.B., Smith, I.M., Dunlap, P.H., and Steinetz, B.M., "Experimental Investigation of Leakage and Compressive Load of Elastomeric Docking Seals," AIAA SPACE 2007 Conference \& Exposition, AIAA-2007-6197, Long Beach, California, 2007.

5. deGroh, III, H.C., Miller, S.K.R., Smith, I.M., Daniels, C.C., and Steinetz, B.M., "Adhesion of Silicone Elastomer Seals for NASA's Crew Exploration Vehicle," Tech. Rep. NASA/TM-2008-215433, National Aeronautics and Space Administration, 2008.

6. Panickar, M., Wasowski, J., and Daniels, C., "Adhesion of an Elastomer Seal to Metal and its Mitigation with Atomic Oxygen Pretreatment," 49th AIAA Aerospace Sciences Meeting including the New Horizons Forum and Aerospace Exposition, AIAA-2011-426, Orlando, Florida, 2011.

7. National Aeronautics and Space Administration, "Project Technical Requirements Specification for the Low Impact Docking System (LIDS) Government Furnished Equipment (GFE)," JSC-63686 Rev. A, 2008.

8. Bastrzyk, M.B., Daniels, C.C., Oswald, J.J., Dunlap, Jr., P.H., and Steinetz, B.M., "Material Properties of Three Candidate Elastomers for Space Seal Applications," Tech. Rep. NASA/TM-2010-216263, National Aeronautics and Space Administration, 2010.

9. Banks, B.A., and Miller, S.K., "Reducing Seal Adhesion in Low Impact Docking Systems," NASA Tech. Briefs, National Aeronautics and Space Administration, Nov. 2010. 


\begin{tabular}{|c|c|c|}
\hline \multicolumn{2}{|c|}{ REPORT DOCUMENTATION PAGE } & $\begin{array}{l}\text { Form Approved } \\
\text { OMB No. 0704-0188 }\end{array}$ \\
\hline \multicolumn{3}{|c|}{ 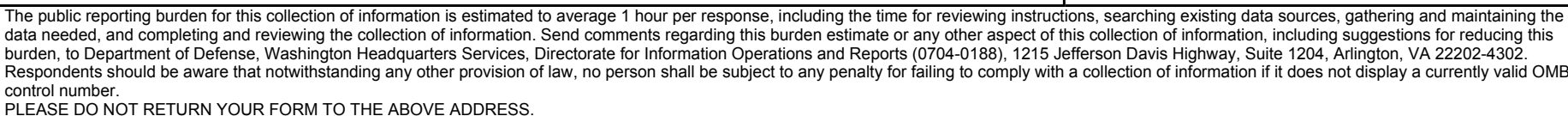 } \\
\hline $\begin{array}{l}\text { 1. REPORT DATE (DD-MM-YYYY) } \\
01-09-2011\end{array}$ & $\begin{array}{l}\text { 2. REPORT TYPE } \\
\text { Technical Memorandum }\end{array}$ & 3. DATES COVERED (From - To) \\
\hline \multirow{3}{*}{\multicolumn{2}{|c|}{$\begin{array}{l}\text { 4. TITLE AND SUBTITLE } \\
\text { Comparison of Adhesion and Retention Forces for Two Candidate Docking Seal Elasto }\end{array}$}} & 5a. CONTRACT NUMBER \\
\hline & & 5b. GRANT NUMBER \\
\hline & & 5c. PROGRAM ELEMENT NUMBER \\
\hline \multirow{3}{*}{\multicolumn{2}{|c|}{$\begin{array}{l}\text { 6. AUTHOR(S) } \\
\text { Hartzler, Brad, D.; Panickar, Marta, B.; Wasowski, Janice, L.; Daniels, Christopher, C. }\end{array}$}} & 5d. PROJECT NUMBER \\
\hline & & 5e. TASK NUMBER \\
\hline & & $\begin{array}{l}\text { 5f. WORK UNIT NUMBER } \\
\text { WBS } 644423.06 .31 .04 .01 .03 .72\end{array}$ \\
\hline \multicolumn{2}{|c|}{$\begin{array}{l}\text { 7. PERFORMING ORGANIZATION NAME(S) AND ADDRESS(ES) } \\
\text { National Aeronautics and Space Administration } \\
\text { John H. Glenn Research Center at Lewis Field } \\
\text { Cleveland, Ohio 44135-3191 }\end{array}$} & $\begin{array}{l}\text { 8. PERFORMING ORGANIZATION } \\
\text { REPORT NUMBER } \\
\text { E-17785 }\end{array}$ \\
\hline \multirow{2}{*}{\multicolumn{2}{|c|}{$\begin{array}{l}\text { 9. SPONSORING/MONITORING AGENCY NAME(S) AND ADDRESS(ES) } \\
\text { National Aeronautics and Space Administration } \\
\text { Washington, DC 20546-0001 }\end{array}$}} & $\begin{array}{l}\text { 10. SPONSORING/MONITOR'S } \\
\text { ACRONYM(S) } \\
\text { NASA }\end{array}$ \\
\hline & & $\begin{array}{l}\text { 11. SPONSORING/MONITORING } \\
\text { REPORT NUMBER } \\
\text { NASA/CR-2011-217109 }\end{array}$ \\
\hline \multicolumn{3}{|c|}{$\begin{array}{l}\text { 12. DISTRIBUTION/AVAILABILITY STATEMENT } \\
\text { Unclassified-Unlimited } \\
\text { Subject Category: } 18 \\
\text { Available electronically at http://www.sti.nasa.gov } \\
\text { This publication is available from the NASA Center for AeroSpace Information, 443-757-5802 }\end{array}$} \\
\hline
\end{tabular}

\section{SUPPLEMENTARY NOTES}

\section{ABSTRACT}

To successfully mate two pressurized vehicles or structures in space, advanced seals are required at the interface to prevent the loss of breathable air to the vacuum of space. A critical part of the development testing of candidate seal designs was a verification of the integrity of the retaining mechanism that holds the silicone seal component to the structure. Failure to retain the elastomer seal during flight could liberate seal material in the event of high adhesive loads during undocking. This work presents an investigation of the force required to separate the elastomer from its metal counter-face surface during simulated undocking as well as a comparison to that force which was necessary to destructively remove the elastomer from its retaining device. Two silicone elastomers, Wacker 007-49524 and Esterline ELASA-401, were evaluated. During the course of the investigation, modifications were made to the retaining devices to determine if the modifications improved the force needed to destructively remove the seal. The tests were completed at the expected operating temperatures of $-50,+23$, and $+75^{\circ} \mathrm{C}$. Under the conditions investigated, the comparison indicated that the adhesion between the elastomer and the metal counter-face was significantly less than the force needed to forcibly remove the elastomer seal from its retainer, and no failure would be expected.

\section{SUBJECT TERMS}

Elastomer; Silicones; Space seals

\begin{tabular}{|c|c|c|c|c|c|}
\hline \multicolumn{3}{|c|}{ 16. SECURITY CLASSIFICATION OF: } & \multirow{2}{*}{$\begin{array}{l}\text { 17. LIMITATION OF } \\
\text { ABSTRACT } \\
\text { UU }\end{array}$} & \multirow{2}{*}{$\begin{array}{l}\text { 18. NUMBER } \\
\text { OF } \\
\text { PAGES } \\
14\end{array}$} & \multirow{2}{*}{$\begin{array}{l}\text { 19a. NAME OF RESPONSIBLE PERSON } \\
\text { STI Help Desk (email:help@sti.nasa.gov) } \\
\text { 19b. TELEPHONE NUMBER (include area code) } \\
\text { 443-757-5802 }\end{array}$} \\
\hline $\begin{array}{l}\text { a. REPORT } \\
U\end{array}$ & $\begin{array}{l}\text { b. ABSTRACT } \\
U\end{array}$ & $\begin{array}{l}\text { c. THIS } \\
\text { PAGE } \\
\text { U }\end{array}$ & & & \\
\hline
\end{tabular}



